\title{
ASEAN and Ongoing Cultural Conflicts
}

\section{Isyana Adriani}

President University

Kampus Jababeka, Cikarang, 17550

Email: isyana.arslan@gmail.com

\begin{abstract}
Abstrak
Artikel ini menganalisis gaya diplomatik dengan menggunakan teori Hofstede's tentang Indikator Dilema Budaya dan menggunakannya untuk menjelaskan mengapa organisasi gagal dalam menghentikan konflik budaya yang sedang berlangsung seperti perselisihan kuil PreahVihear. Terdapat 13 indikator dilema budaya di diskusikan dalam Artikel ini, Masing-masing didukung dengan contoh yang akhirnya mengarah pada kesimpulan bahwa pemerintah setiap Negara anggota ASEAN harus berinvestasi dalam jangka panjang dan solusi-solusi yang efektif. Solusi ini diperlukan karena ASEAN dimulai pada Komunitas ASEAN (AC) yang dijadwalkan untuk berlangsung pada tahun 2015, dan karena artikel ini mengenai gaya diplomasi organisasi dalam menyoroti kelanjutan konflik budaya, fokusnya adalah pilar komunitas Sosial dan Budaya AC. Rekomendasi yang diberikan dalam artikel ini dibutuhkan tidak hanya untuk mempersiapkan masyarakat ASEAN untuk perubahan besar yang akan dibawa AC dalam konteks budaya, tapi juga untuk memperbaiki citra ASEAN dimata observer luar Asia Tenggara yang memandang organisasi ini tidak lebih dari "talk shop". Secara keseluruhan mereka berkontribusi pada Komunitas ASEAN yang sukses.

Kata Kunci: Konflik budaya, komunitas ASEAN, gaya diplomatic
\end{abstract}

\begin{abstract}
This paper analyses ASEAN's diplomatic style using Hofstede's theory of Cultural Dilemma Indicators and uses it to explain why the organization has failed to stop on-going cultural conflicts such as the PreahVihear temple dispute. There are 13 cultural dilemma indicators discussed in the paper, each is backed with an example which in the end leads to the conclusion that the government of each ASEAN member state must invest in longterm yet effective solutions. These solutions are necessary since ASEAN is embarking on ASEAN Community (AC), which is slated to take place in 2015, and since this paper is about the organization's diplomatic style in light of continuing cultural conflicts, the focus is on AC's Socio-Cultural Community pillar. The recommendations offered in this paper are necessary not only to prepare ASEAN people for major changes AC will bring in the context of culture, but also to rectify ASEAN's image in the eyes of observers outside Southeast Asia who view the organization as nothing more than a "talk shop." As a whole, they contribute to a successful ASEAN Community.

Keyword: Cultural Conflict, ASEAN Community, diplomatic style
\end{abstract}

\section{INTRODUCTION}

In the 47 years since the establishment of The Association of Southeast Asian Nations (ASEAN) since August 8 1967, the organization has seen many significant events. These events ranged from an addition of Brunei Darussalam in 1984, followed by Vietnam, Laos, Burma and Cambodia in 1995, 1997 and 1999, to a myriad of conflicts such as the dispute over the PreahVihear temple in the border of Thailand and Cambodia. This writing looks at the cultural disputes within ASEAN countries such as the afore- mentioned conflict between Cambodia and Thailand, as well as the never-ending disputes between Malaysia and Indonesia over heritage aspects such as Reog dance and "Rasa Sayange" folk song, and analyzes ASEAN's failure to overcome such disputes using Geert Hofstede's 13 Cultural Dilemma Indicators.

\section{ANALYSIS}

CULTURAL DILEMMA INDICATORS IN ASEAN DIPLOMACY

Cultural Dilemma Indicators were first coined by 
Dutch anthropologist Geert Hofstede in 1971, and it has been used to analyze cultural differences amongst many different countries. The first cultural dilemma which is put to work in this essay is power distance. At its establishment, ASEAN was signed by the Foreign Affairs Ministers of Indonesia, The Philippines, Thailand, Malaysia and Singapore. These Foreign Affairs Ministers represented the then heads of said countries, amongst whom were Soeharto, Ferdinand Marcos and Lee Kuan Yew. Since the power distance element of Cultural Dilemma Indicators looks at the distance of power between a leader and his subjects, we cannot ignore the facts that the leaders of five signing members of ASEAN at that time were dictators. As with many dictatorial countries, there is a huge distance between a leader and his people, which explains that all state decisions are determined by head of state. This also explains that although ASEAN aims to be a people-oriented organization, the people of member states have never really been involved in organizational matters. Decision-making process in ASEAN stops at ministerial level, and each state representative only carries in mind the interests of his own country. ${ }^{1}$

That brings us to the second indicator: individualism vs collectivism. It is indeed true that Asian countries are known for being collectivist. South East Asian countries are no exception, for example is Indonesia where "musyawarah untuk mufakat" is conducted to reach a decision that benefits all the parties involved. However, in terms of government-to-government (G2G) matters ASEAN leaders have been individualistic. Syaltout, Polimpung and Rahmani (2012) especially observed the military relations of ASEAN countries with non-ASEAN ones to prove this individualistic trait. In their observation, ASEAN countries turn out to prefer military relations with more developed countries that are geographically far from South East Asia, such as The United States of America (USA) and Japan, than with each other. This is also shown in their trade relations, with Singapore having Free Trade Agreement (FTA) with Australia, China and India. This individualism may become an obstacle in ASEAN Community that is slated to take effect in $2015 .^{2}$

Next is the diffuse nature (from the cultural dilemma of diffuse versus specific) of ASEAN diplomacy strategies, which looks at how diplomacy amongst ASEAN countries has mostly been done in a leisurely manner. ASEAN countries have been known for applying the golf diplomacy and the durian diplomacy, in which state heads would play golf and eat durians while talking about their wives and children before finally, hours later, they get down to business. Even after they finally discuss matters at hand, sometimes they do not reach a significant decision, and their spokespersons would release statements to the media saying the issues need further discussion. This has caused ASEAN to be perceived as a "talk shop" by non South East Asian observers, with its never-ending summits and forums that barely reach any important decision that is put to action.

Closely related to this diffuse characteristic is masculinity versus femininity. So far, the only ASEAN leaders who showed masculinity in their leadership were former Indonesian President Soekarno and former Prime Minister of Malaysia Mahathir Mohamad. In 1963, in the wake of border disputes with Malaysia in the island of Kalimantan, Soekarno started a movement that was later known as "Ganyang Malaysia", and in 1981 Mahathir Mohamad launched the "Look East" policy which prioritized Asian investors over Western ones. Their predecessors and successors have been concerned about the choice of words for press releases, to avoid conflicts in line with ASEAN's non-intervention principle - in other words, showing traits of femininity. ${ }^{3}$

Another dilemma indicator that is close to masculinity versus femininity and diffuse versus specific is neutral versus emotional. With the exception of Soekarno, ASEAN leaders have been known to be concerned with their composure in the public eye. As mentioned earlier, they choose their words carefully, make sure they stand in the right posture and look good in crisp clothes. This maintenance of a good public image is also in line with ASEAN's way of non- 
intervention and non-confrontation. One outstanding example of this is another former Indonesian President Megawati Soekarno Putri, Soekarno's daughter, who came to power after the impeachment of President Abdurrahman Wahid in 2001. In deep contrast with her father, Megawati Soekarno Putri is remembered for refusing to give comments in light of many issues, causing many to question her leadership skills. This neutral characteristic of ASEAN leaders is starkly different from the fiery style of former president of USA George W. Bush and the energetic style of current US president Barrack Obama, showing an emotional side of this cultural dilemma indicator. ${ }^{4}$

It is also important to look at ASEAN through another cultural dilemma indicator, uncertainty avoidance. Uncertainty avoidance level differs from one country to another, but a common pattern that is found in ASEAN countries which showcases this indicator is the member states' semi authoritarian government. Myanmar is a good example of this dilemma since the Junta military government avoids uncertainty by banning anything that comes out of Myanmar. The junta denied The National League of Democracy (NLD)'s right to rule as the landslide winner of the 1990 election and put NLD leader Aung San SuuKyi under house arrest partially because SuuKyi spent her youth in England and was married to an English man, therefore posing a threat to Myanmar. She was thought to be a spy of sorts for England. Myanmar's fear of anything foreign has its roots in the country's past, in which during the British occupation the native Burmese ethnic was at the bottom of society, below Europeans, Indians and Eurasians (people of Burmese-European mixture.) This also explains why the Muslim Rohingya have always been severely oppressed, as ethnically Rohingya are closer to Indians than the Burmese.

From this example, this uncertainty-avoiding characteristic of Myanmar results in ASEAN's uncertainty-avoiding diplomacy towards the country. In 2012, in the wake of 80 Muslim Rohingya's being killed in a social unrest in Rakhine while the Myanmar government did nothing, Indonesia as a country with the biggest, most diverse Muslim population in the region was willing to lend a helping hand. However, instead of being directly involved, Foreign Affairs Minister Marty Natalegawa appointed Organization of Islamic Conference (OIC) to take care of the Rohingyas in Myanmar and Rohingya refugees outside the country. This was conducted after Myanmar President TheinSein's preference for United Nations to grant the Rohingyas refugee status was not approved by then US Secretary of State Hilary Clinton. Natalegawa's appointment of OIC in this case can be seen as another act of non-intervention and nonconfrontation, but according to Luke Hunt in his article for "The Diplomat", "Indonesia's Moral Diplomacy”, Indonesia's choice of OIC could also be a way to avoid uncertainty as to how other ASEAN members and Myanmar itself would react should Indonesia be directly involved. ${ }^{5}$

Despite this uncertainty avoidant nature of ASEAN member states, to the point of avoiding anything foreign, the organization does have partnerships with non South East Asian countries, on which the cultural dilemma indicator of universalism versus particularism will be based. Until 2002, ASEAN applied a non legally binding policy to non ASEAN member partners. This is when ASEAN attempted to ratify "Declaration of The Conduct of Parties in South China Sea" with China. This declaration explores the maritime potentials of South China Sea while respecting the sovereignty of China over the territory. Since its signing in Vietnam in 2002, the declaration seems to be put to work smoothly. According to Xianhuanet.com on October 17 2013, China has prepared funds amounting to US\$ 491 million to build a 21st century maritime Silk Road for the next eight years, which will benefit China and South East Asia and help reach the goal of reaching a trade volume of US\$ 1 trillion by 2020 . In addition to that, China has also set up individual partnerships with respective member states of ASEAN still in the framework of "Declaration of The Conduct of Parties in South China Sea", such as five-year economic and trade plans with Malaysia and Indonesia. That is what 
seems to be on the outside. The Philippines, Vietnam, Brunei Darussalam and Malaysia have all laid claim on the resource-rich South China Sea, to the displeasure of China. It is apparent that China is using ASEAN to boost its economic influence to cement sole claim on South China Sea, and it reflects on a statement by Chinese Premier Li Kegiang as quoted from Confucius, "He who has experience with chopsticks understands that a single chopstick will not do the work of putting food in the mouth." It is unusual to continue a legally binding partnership despite conflicts that have happened behind the scene for 11 years since the declaration was signed, therefore we could say that "Declaration of The Conduct of Parties in South China Sea" is particularist rather than universalist. ${ }^{6}$

According to Shaun Nerine in "The English School and ASEAN" (2006), ASEAN is in possession of a cultural dilemma indicator of orientation to past, rather than the present and future. ASEAN seems obsessed with repeating past successes with little vision to the future. Also according to Nerine, this obsession with past successes is driven by the government's need to save the state budget by not exploring new ways to face possible challenges in the future. Orientation to the past in ASEAN is even apparent in ASEAN Vision 2020, where it states that ASEAN "envision the entire South East Asia to be, by 2020, an ASEAN community conscious of its ties of history, aware of its cultural heritage and bound by a common regional identity."

The ninth cultural dilemma indicator to look at for a better understanding of ASEAN diplomacy style, which has led to failure to stop cultural conflicts from continuing, is achievement versus ascription. According to Syaltout, Polimpung and Rahmani (2013), ASEAN diplomatic culture is achievement-oriented, and what is meant by achievement orientation here is orientation to past achievements. Morten F. Greve wrote in "ASEAN Down the 'EU Way'? Cooperation and Conflict" (2004) that this past achievementoriented style of ASEAN diplomacy has caused European Union (EU) to mock the organization for focusing its economic integration to repeat past glories. This indicator is very much like the indicator of past orientation that is discussed in the previous paragraph, and runs contrary to the ascription-oriented nature of the people of ASEAN member states. ${ }^{8}$

Next on the list is synchronic versus sequential, which looks at how relationships are maintained. ASEAN diplomacy is both sequential and synchronic, depending on which angle it is seen from. It is synchronic if it is seen from the way ASEAN member states are still in close contact with one another, as a trait of a synchronic society is maintaining a relationship well beyond its time frame and interests. It is also sequential in terms of the many meetings and summits that have been held, which are arranged in certain time frames and followed through until it is finished.

When an agreement is achieved and involved countries deem their interests have been fulfilled, they go back to their individual state matters, very often helped by more powerful countries that are not members of ASEAN. An example of this is the relations between Cambodia, The Philippines and China in "Declaration of Conduct of The Parties in South China Sea." In November 2012, Cambodian Prime Minister Hun Sen as last year's Chairman of ASEAN declared that the organization members had agreed that they would not internationalize their disagreement with China about the latter's claimed sovereignty over South China Sea. Knowing that the consensus was fictional, President of The Philippines Benigno Aquino Jr. countered the statement by holding a meeting in Manila on December 12 2012. According to Trefor Moss in "ASEAN: A Diplomatic Dead End" which is published on TheDiplomat.com, this meeting did not interest most ASEAN members and only excited the four ASEAN claimants on South China Sea: The Philippines, Brunei Darussalam, Vietnam and Malaysia. In addition to that, Cambodia sided with China since the regional powerhouse has been its strongest ally amidst sanctions from USA and Europe. This shows that at least in the case of the South China Sea conduct declaration which is in its 11th year now, the matter is only tended to sporadically and Cambodia, as well as other ASEAN member states in alliance with China such as Myanmar, prefers to take care of their 
cooperation with more powerful non-ASEAN member countries. 9

In the indicator of internal control versus external control, we are going to look at how ASEAN member states determine the direction of their policy. According to Evelyn Goh (2005), ASEAN countries are more internal than external in determining their policy direction, and this internal control indicator in ASEAN diplomacy style is related to their individualistic trait. As discussed earlier, ASEAN leaders may have forums, summits and meetings about integration on many fronts, but each leader only brings forth mind his/her state interests and this shows individualism. This individualistic trait leads to the fact that in ASEAN no one member state is a major power that has dominance over smaller, weaker countries when it comes to determining policy. It means that the sovereignty of member states is not threatened. Therefore, internal control here means that no member state could become an external power that could put pressure on fellow members in determining respective policy. This is especially apparent in the way no ASEAN member put any sanction on Myanmar when the junta government not only house arrested NLD leader Aung San Suu Kyi but also arrested bloggers who dared report the inside situation of the country without trial and refusing to grant foreigners visa. In other words, this internal control reflects the non-intervention trait of ASEAN. ${ }^{10}$

In terms of long term versus short term orientation, it is known that ASEAN has planned ASEAN Community of 2015 since the 2003 Bali Concord II with three pillars that include ASEAN Security Community. This shows that ASEAN is long term oriented. However, this long-term orientation is not supported by how member states have spent their military budget of late. For example, from 2003 to 2010 Indonesia purchased Sukhoi planes from Russia which were dispatched gradually and in October 2012 Indonesia purchased Leopard 2A6 main battle tanks also from Russia. The battle tanks have been gradually shipped to Indonesia until October 2014. Thailand has also increased its military spending since 2006 in the wake of its dispute with Cambodia over the PreahVihear temple. Vietnam has also been increasing its military spending in anticipation of a war with China regarding claim on South China Sea. This shows that despite long term orientation as reflected in ASEAN Community 2020, ASEAN member states are occupied with short term goals of protecting their sovereignty from potential external threats. ${ }^{11}$

The last of 13 Cultural Dilemma Indicators is indulgence versus restraint. ASEAN is indulgent according to Syaltout, Polimpung and Rahmani (2013) because ASEAN countries tend to be lenient in regards to law violation. An easy example would be how Indonesian migrant workers in Malaysia are not treated well, some of them were killed by their employers, but no firm action has been taken against Malaysia. This is in line with the organization's nonintervention and non-confrontation policy, but this laid back stance against violation of law actually supports graft that is ripe all over the region. An example of how this non-intervention policy allows graft to grow rampant in South East Asia and beyond is the illegal logging by Asia Pacific Resources International Holdings Ltd. (APRIL), a mere section of which involves Cambodia, Thailand and China. On April 26 2012, Cambodian journalist Chan Wutty was shot to death after he refused to hand over his camera memory card to the police in the Koh Kong province, Cambodia, a site where rosewood is illegally logged and taken to China to be made into furniture and musical instruments that are exported to The US. The illegal logging is also conducted in the woods of Thailand and Thai police officers have shot Cambodian illegal loggers on the spot. No justice has ever been brought to Chan Wutty's case, but there is no doubt that he was killed by APRIL backed the government that is supposed to protect the woods from deforestation. 12

With the 13 Cultural Dilemma Indicators that explain the nature of ASEAN diplomatic style, there is not a wonder why cultural conflicts are still occurring and will continue to occur. If ASEAN leaders continue to be individualistic in the sense that they only 
think about their state interests where economic and cultural integration are concerned, their indulgent trait allows graft to flourish and the diffuse nature of ASEAN diplomacy continues to emphasize style rather than reaching significant decisions, existing cultural conflicts will continue and new ones will emerge. Many have doubted ASEAN's ability to bring ASEAN Community 2015 into being, and if it does come into being it would be unlikely to last long. The next part will have a look at the future of ASEAN in ASEAN Community 2015, incorporating the current challenges the organization is facing and focusing on the pillar of Socio-Cultural Community, which aims to realize an ASEAN Community that is people-centered to achieve solidarity and unity amongst ASEAN people.

\section{CURRENT CHALLENGES AND FORAY INTO ASEAN SOCIO- CULTURAL COMMUNITY}

ASEAN Socio-Cultural Community's complete vision is to "contribute to realizing an ASEAN Community that is people-centered and socially responsible with a view to achieving an enduring solidarity and unity among the nations and peoples of ASEAN by forging a common identity and building a caring and sharing society which is inclusive and harmonious where the well-being, livelihood and welfare of the peoples are enhanced." Taking a glance at the cultures of ASEAN member states, we will see a lot of similarities in languages (Bahasa Melayu of Malaysia and Bahasa Indonesia of Indonesia, even Tagalog of the Philippines is a bit similar with both languages), food, traditional clothes and many other aspects. So far, these similarities have served as a double-edged sword. Not only do they tie ASEAN member states together in a sense of brotherhood - whether real or perceived but said similarities are also a source of disputes.

According to former ASEAN Secretary General Surin Pitsuwan from Thailand in an interview with ASEAN News on March 6 2013, despite all these cultural similarities ASEAN member countries do not have a "we feeling." Indonesians, for example, do not think of themselves as Indonesians and "ASEAN-ers" (as Pitsuwan put it.) He also said that it was important to change the way history was taught at ASEAN schools to reach the goal of realizing a united ASEAN that cares about one another. Pitsuwan said so far history lessons emphasized heroes and heroines that fought only for national interests, including those who invaded neighboring countries. The change in how history is taught is necessary so children and youngsters will not be indoctrinated to be greedy, selfish and most importantly, they will not see events only through the perspective of national interests. ${ }^{13}$

The media also plays a very important role in shaping a good image for ASEAN. Director of Inter Press Service (IPS) Asia Pacific Johanna Son wrote in an article titled "ASEAN: Useless Body, Super Power or Somewhere in Between?" that when ASEAN holds meetings or summits, a couple of images come to the minds of the people: smiling leaders and traffic jams the events cause. There is also another image which springs to mind when it comes to ASEAN in general, that is of a super body expected to resolve any conflict but unable to, hence the term "paper tiger." According to Son, the media has to focus on the real issues being discussed in summits and meetings instead of the high profile of said events. The media people have to carry in mind the question "What is ASEAN about?" while covering the organization because many people in ASEAN member countries only know mostly its history. They hardly know how ASEAN works, how ASEAN has impacted the respective state policy and how it in turn impacts their lives. ${ }^{14}$

This task of informing people what ASEAN is really about and how it can impact their lives should be hand in hand with ASEAN leaders' awareness that the organization has not involved people. Unfortunately, until ASEAN leaders leave their predecessors' "dictators' club" legacy which sees matters only discussed in a G2G manner, said leaders will only be worried about saying the right things to the media and the media will only focus on the meetings or summits. In the end, the people's knowledge of ASEAN will not get any further than the history. 


\section{CONCLUSION}

Surin Pitsuwan, who was ASEAN's Secretary General in the period of 2008-2012, said that it would a long time for the regional organization to be a community likes EU. It will be a long time until an "ASEAN-er" will only need one passport to travel anywhere he likes in Southeast Asia, which is something ASEAN Community aims for, though according to Pitsuwan it does not aim to have one currency upon learning from the experience of EU with Euro. From a historical angle, it took EU 36 years to become a supranational union that surpasses the notion of a nation, since the establishment of European Community in 1957.

To draw a conclusion, cultural conflicts within ASEAN member countries will still continue given the nature of not only its diplomacy but also the cultural characteristics of said countries as analyzed using 13 Cultural Dilemma Indicators. It takes a long time for a human being to change, and it is the same with countries. It will be decades until ASEAN leaders stop being individualistic on the G2G level, after ASEAN people stop thinking of themselves as a nation only but also as "ASEAN-ers." It will be many years until ASEAN leaders stop applying leisurely diplomacy only to release statements to the media that another summit or meeting is needed to reach a decision.

ASEAN Community 2015 is hotly anticipated by the world as the old power that is Europe and The US are weakening of late, with the recent shut-down of the US government and the monetary crisis that many European countries have been experiencing. Many want to jump on the South East Asian bandwagon as the region is predicted to outperform its neighboring East Asian and South Asian economic giants China and India when ASEAN economies are integrated in ASEAN Economic Community (AEC) also in 2015. This economic integration will not happen without investment in public education, as explained by Asian Bank Development (ABD) President Haruhiko Kuroda during the 45th annual meeting of ABD board in Manila in 2012, which shows that without any socio-cultural improvement
AEC, which will lower trade tariffs and ease employment restriction all over the region, will not happen. 15

With the 13 Cultural Dilemma Indicators to explain the psychological factors of ASEAN diplomacy that have contributed to the organization's failure to stop cultural conflicts from continuing, we have come to a conclusion that for any conflict - cultural or otherwise - to stop there has to be a change in the ASEAN psyche itself. This change needs a lot of investment and a long time to bear fruit, just like any change we would like to see regarding soft power diplomacy. It is better to start investing in an education system that instills in young people to see themselves not just as a nation but also part of ASEAN now, rather than waiting until AEC takes place in 2015 when ASEAN people can get employment anywhere in the region. So far, the only major change in education is the birth of international standard system which allows national schools in non English speaking ASEAN member states to use English as language of communication as a way to increase competitiveness in the AEC open job market. No school yet teaches their students to accept fellow ASEAN-ers as brothers and sisters with equal opportunity and shared heritage. If ASEAN governments invest in the kind of education system that teaches youth that they are part of ASEAN, it will have a positive domino effect that will see changes in the 13 Cultural Dilemma Indicators which describe ASEAN diplomacy, although these changes are unlikely to materialize in the near future. In the end, these positive transformations will change the non-intervention and non-confrontation trademark of ASEAN diplomacy, which has proven to be not very effective since the birth of the organization.

\section{ENDNOTES}

Mahmud Syaltout, et al., Dilema Kultural Dalam Strategi Diplomasi Indonesia di ASEAN, (Jakarta: UI Press, 1979), 48-50

Ibid

Ibid

Ibid

Luke Hunt, "Indonesia's Moral Diplomacy", TheDiplomat.com, August 17, 2012, http://thediplomat.com/asean-beat/2012/08/17/ 
indonesias-moral-diplomacy/ (accessed October 30, 2013).

6 Yang Yi, "Oriental Wisdom Opens New Chapter of ASEAN-China Ties," Xianhuanet.com, October 17, 2013, http:// news.xinhuanet.com/english/china/2013-10/17/c_132807577.htm (accessed October 20, 2013).

7 Shaun Narine, "The English School and ASEAN," Pacific Review 19, no. 2 (2006): 203-205.

8 Morten F. Greve, "ASEAN Down The 'EU Way'?,Cooperation and Conflict 39, no. 2 (2004): 207-212.

9 Trevor Moss, "ASEAN: A Diplomatic Dead End?", TheDiplomat.com, November 23, 2012, http://thediplomat.com/flashpoints-blog/ 2012/11/23/asean-a-diplomatic-dead-end/ (accessed on October 23, 2013).

10 Evelyn Goh, "Great Powers and Hierarchical Order in Southeast Asia: Analyzing Regional Security Strategies." International Security 32, no. 3 (2007): 136-140.

11 Syaltout, et al., DilemaKulturalDalamStrategiDiplomasi Indonesia di ASEAN, 58-60.

12 Charlie Campbell, "In Cambodia, China Fuels Deadly Illegal Logging." Time.com, May 14, 2013, http://world.time.com/2013/05/14/incambodia-illegal-logging-unabated-on-anniversary-of-leadingactivists-death/ (accessed October 25, 2013)

13 SujaneKanparit, "Q\&A: It Will Take Time Before ASEAN is A Complete Community." ASEANNews.net, March 6, 2013, http:// www.aseannews.net/qa-it-will-take-time-before-asean-is-acomplete-community/ (accessed October 24, 2013).

14 Johanna Son, "ASEAN: Useless Body, Superpower, or Somewhere in Between?",ASEANNews.net, September 5, 2012, http:// www.aseannews.net/asean-useless-body-superpower-or-somewhere-in-between/ (accessed October 25, 2013).

15 Michelle V. Remo, "ASEAN Seen as Economic Growth Force by 2015." Inquirer.net, May 5, 2012, http://newsinfo.inquirer.net/ 187759/asean-seen-as-economic-growth-force-by-2015 (accessed October 29, 2013.)

\section{BIBLIOGRAPHY}

Campbell, Charlie. "In Cambodia, China Fuels Deadly Illegal Logging Trade." Time.com, May 14, 2013, (accessed October 25, 2013)

http://world.time.com/2013/05/14/in-cambodia-illegal-loggingunabated-on-anniversary-of-leading-activists-death/

Goh, Evelyn. "Great Powers and Hierarchical Order in Southeast Asia: Analyzing Regional Policy Strategies." International Security 32, no. 3(2007): 136-140.

Greve, Morten F. "ASEAN Down The 'EU Way'?" Cooperation and Conflict 39, no.2 (2004): 207-202.

Hunt, Luke. "Indonesia's Moral Diplomacy."TheDiplomat.com, August 17, 2012,

http://thediplomat.com/asean-beat/2012/08/17/indonesias-moraldiplomacy/ (accessed October 30, 2013).

Kanparit, Sujane. "Q\&A: It Will Take Time Before ASEAN is A Complete Community." ASEANNews.com, March 6, 2013, (accessed October 24, 2013).

http://www.aseannews.net/qa-it-will-take-time-before-asean-is-acomplete-community/

Moss, Trefor. "ASEAN: A Diplomatic Dead End?" TheDiplomat.com,
November 23, 2013, (accessed October 23, 2013).

http://thediplomat.com/flashpoints-blog/2012/11/23/asean-adiplomatic-dead-end/ Narine, Shaun. "The English School and ASEAN."Pacific Review 19, no. 2 (2006): 203-205.

Remo, Michelle V. "ASEAN Seen as Economic Growth Force in 2015." Inquirer.net, May 5, 2012, (accessed October 29, 2013).

http://newsinfo.inquirer.net/187759/asean-seen-as-economic-growthforce-by-2015

Son, Johanna. "ASEAN: Useless Body, Superpower or Somewhere in Between?"ASEANNews.net, September 5, 2012, (accessed October 25, 2013).

http://www.aseannews.net/asean-useless-body-superpower-orsomewhere-in-between/

Syaltout, Mahmud.,HizkiaYosiasPolimpung and Aziz Rahmani. Dilema Kultural Dalam Strategi Diplomasi Indonesia di ASEAN. Jakarta: UIPress, 2013.

Yi, Yang. "Oriental Wisdom Opens New Chapter of ASEAN-China Ties." Xinhuanet.com, October 17, 2013, (accessed October 20, 2013.)

http://news.xinhuanet.com/english/china/2013-10/17/ c_132807577.htm, 